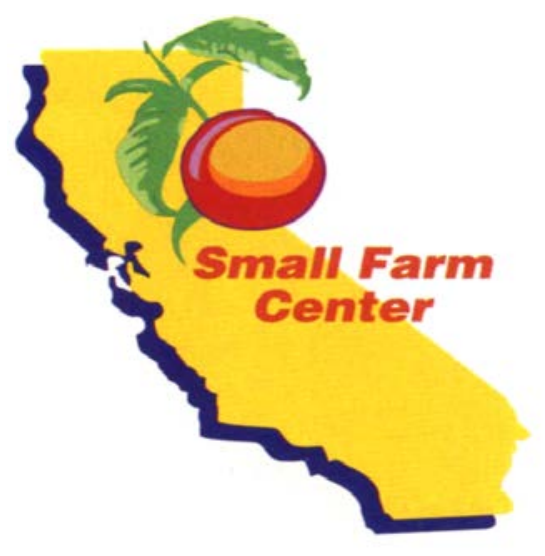

\section{Stories of success and struggle: California's small farms}

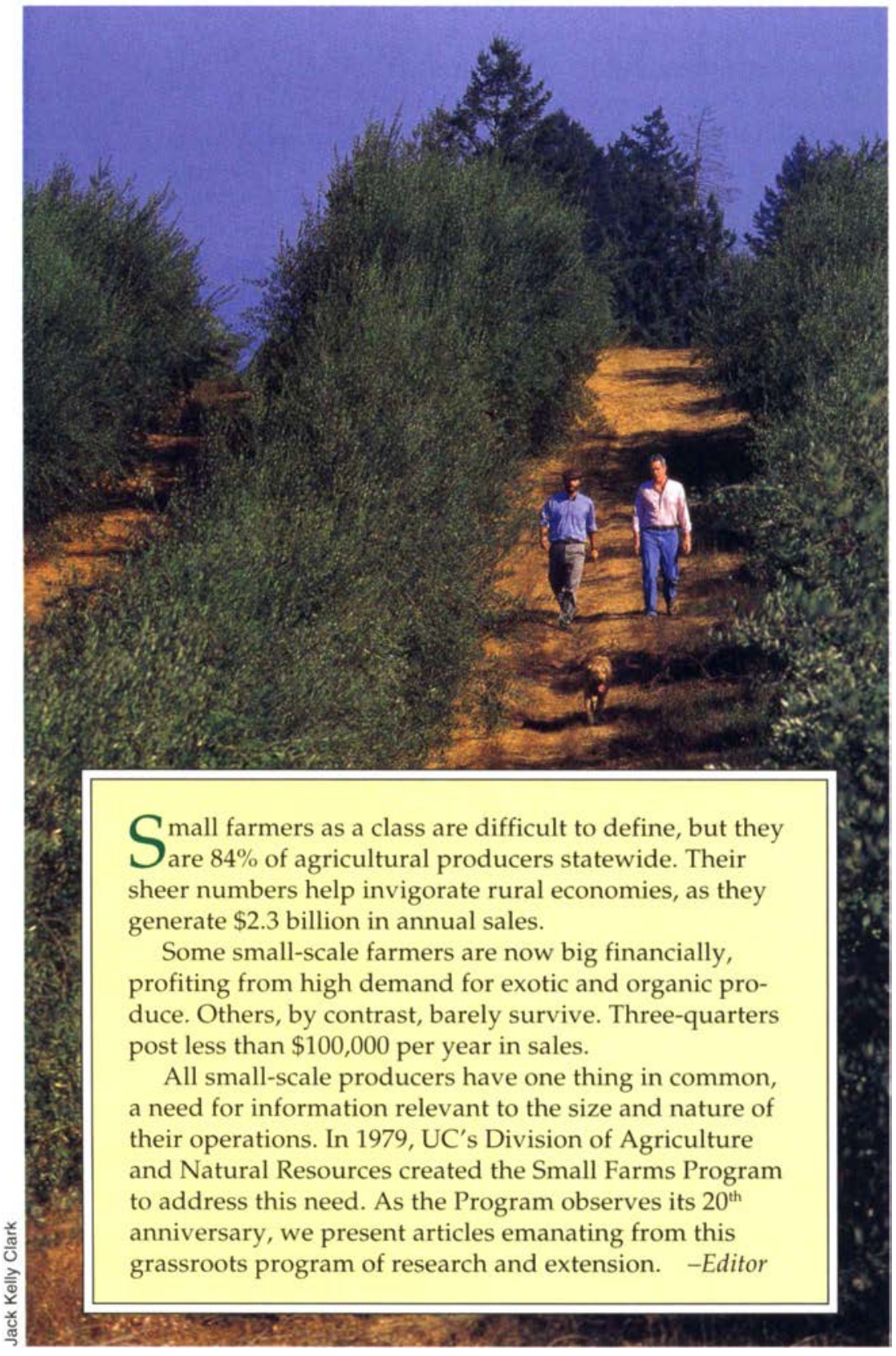

alifornia small-scale farming is a story of success for some, and struggle for others. It may reflect a personal commitment to country living, working the land and producing a wholesome product. Or it could be the only option for people whose education and experience limits them to scratching out a living on a small leased plot.

Many of the small farms flourishing in rural California have capitalized on market niches created by new consumer trends, such as the popularity of "California cuisine," which features fresh and specialty products. The growing interest in organic agriculture, farmers' markets and agritourism has also expanded markets for small farms.

Kathleen Barsotti is a Capay Valley farmer who, in a period of more than two decades, has built her business from a struggling enterprise with rarely enough money to pay the bills into a prosperous 70 -acre operation selling organic produce to wholesalers, gourmet restaurants, farmer's markets and a network of subscribing consumers.

"I'm exactly where I always wanted to be," she says.

Combining wildlife habitat and healthful living, creating good food and a diverse biological system has been the life's work of Dru Rivers and Paul Muller, who for 15 years have managed Full Belly Farms, a successful organic operation also in the Capay Valley. They owe their success to long hours, persistence and dedication.

"We are personally in love with our farm," Muller says. "It is such a right livelihood for us."

Near Watsonville, Nita Gizdich and her husband Vince transformed a sleepy 50-acre family farm into a thriving business that serves fresh apple juice and apple pie, apple-themed gifts and antiques to suburbanites who've dropped by to enjoy a day in the country picking fresh fruit.

"We would never have survived just by growing berries and apples," Gizdich says.

Farmers like these have used excellent production, management and marketing skills to propel themselves beyond the $\$ 250,000$ gross income limit the USDA uses to define a small farm. Others, the limited-resource farmers with 
gross sales under $\$ 100,000$, often barely turn a profit.

Many of the limited-resource farmers have fallen victim to intense competition, expensive inputs, excessive regulations, and unpredictable weather. In California, more than 3,000 small farms closed shop between 1992 and 1997.

In the desert of Riverside County, for example, farmers struggle to survive. Local farmer-to-consumer sales are not an option here.

"Weather is the biggest factor in this area," says farm advisor José Aguiar. "The temperatures can reach 110 degrees in the early morning and stay high until late in the afternoon. If consumers travel anywhere to purchase produce, it will be to an air-conditioned store to shop in comfort. The City of Indio spent considerable energy to develop a farmers' market in downtown, but it did not survive the first summer."

In 1998, the National Commission on Small Farms released a report urging the federal government to act immediately to save small limited-resource farms from disappearing.

"If we do not act now, we will no longer have a choice about the kind of agriculture we desire as a nation," the 30 -member commission concluded in a 120-page report titled "A Time to Act."

The commission found that most profits in agriculture go to companies that process food and sell products to farmers.

"Small-scale farmers are typically squeezed at both ends of the economic spectrum," says Desmond Jolly, director of UC's Small Farm Program and co-vice chair of the commission. "The inputs they purchase - such as fertilizers, chemicals and equipment - are increasingly expensive, while their products are sold into markets that are concentrated and tend to depress prices to the grower."

Observing its 20th anniversary this year, UC's Small Farm Program was established in 1979 to ensure the state's small-scale and family farmers are not relegated to history books. The program is dedicated to assisting California small-scale farmers, including the estimated three-quarters that operate under conditions of limited resources. By providing access to such farming necessities as research, state-of-the-art information, support networks, assistance with technology adoption and decision making, the program is helping small-scale farms become secure and sustainable.

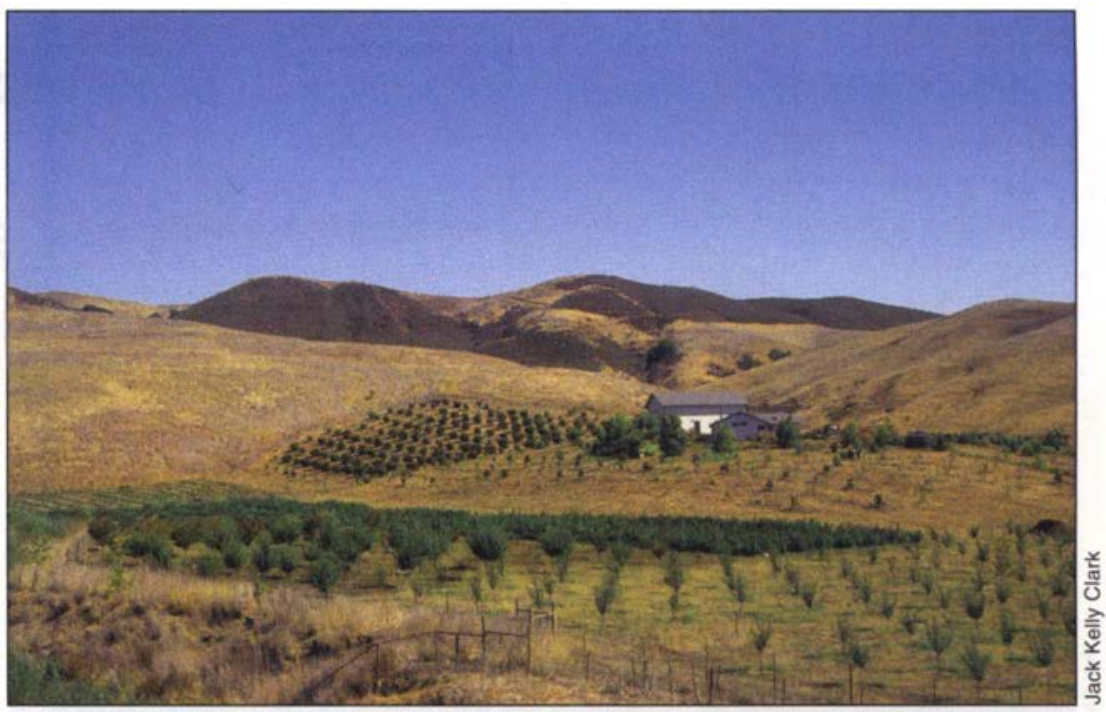

Small family farms like this blueberry ranch near Cayucos make environmental, social and economic contributions to rural communities. The UC Small Farm Program endeavors to help a larger proportion of the state's small farms operate profitably.
- Small Farm Workgroup, which includes 75 farm advisors, specialists and other smallfarm-related professionals and paraprofessionals.

- Small Farm Program Advisory Committee, which includes farmers and representatives of farmers' markets, sustainable agriculture groups, farm organizations, county agricultural commissioners' offices and other organizations that represent farmers and farm workers.

- Farm advisors in San Diego, Riverside, Santa Barbara/San Luis Obispo, Tulare, Fresno, San Joaquin and Santa Cruz counties.

One focus of the Small Farm Program's seven farm advisors' efforts is research. Farm advisor Richard Molinar works with predominantly immigrant small-scale farmers in Fresno County. He says there is a need for funds to conduct more on-farm research and hire bilingual assistants.

"We have only two registered pesticides for luffa," he says, speaking of a sharply ridged, cucumber-shaped vegetable popular with Southeast Asian-immigrants. "For opo and lemongrass, we have none. Of the 90 specialty crops we work with, only one has a commodity board. Finding money to conduct research is very difficult."

Farm advisor Mark Gaskell, based in Santa Barbara County, says local small-scale farmers were struggling with severe root rot in edible 


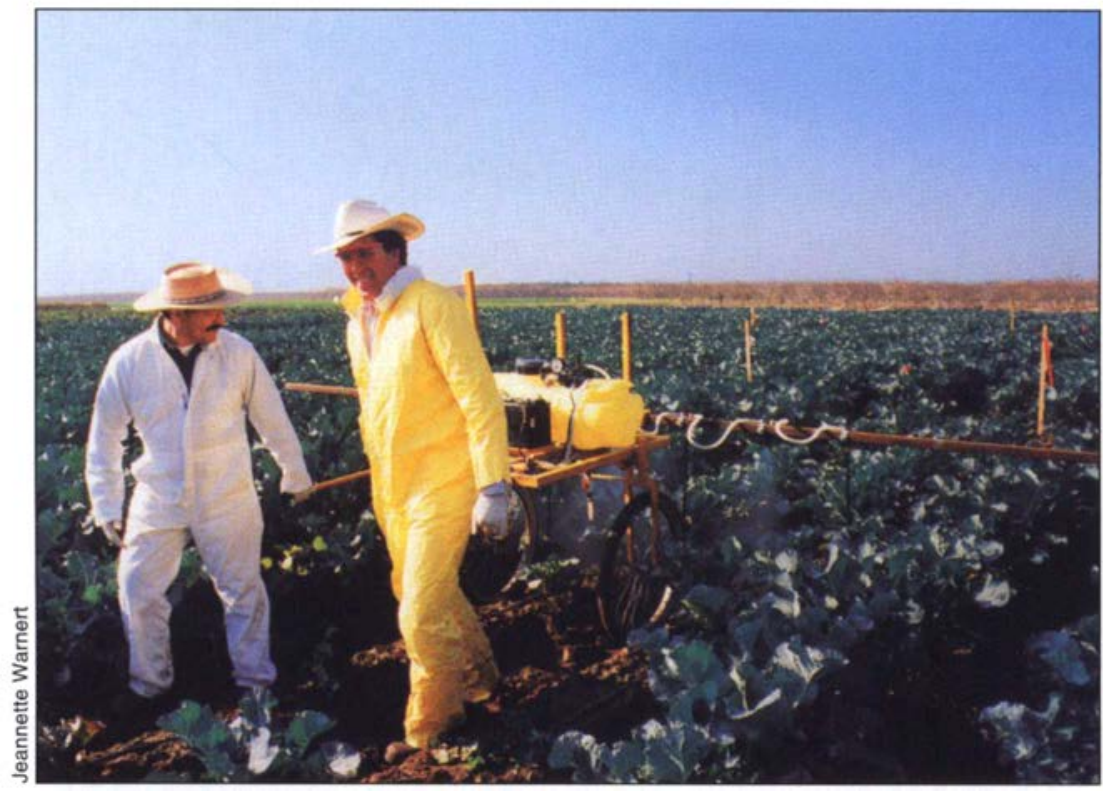

Manuel Jimenez and Tim Prather demonstrate how the bicycle sprayer works.

pod peas, which for 20 years had been the mainstay of specialty farming on the Central Coast. However, he found, none of the farmers was making money on the crop.

"What we really needed to do was develop new crops, analyze market windows, and look for alternatives to growing the edible pod peas," he says.

Several Small Farm Program advisors are undertaking research to identify new crops for small-scale farmers. Gaskell is researching Central Coast blueberry production. In San Joaquin County, farm advisor Benny Fouche has grown artichokes, a crop more common on coastal farms.

"The artichokes appear to do very well here," Fouche says.

Fresno County's advisor Molinar is looking at the medicinal herbs echinacea, jujube tree, ginseng and goldenseal. Tulare County Small Farm Program advisor Manuel Jimenez is studying the production of blueberries and blackberries on small plots at the UC Kearney Agricultural Center near Parlier.

The new crops may open market windows for small farmers who cannot compete with large-scale growers producing traditional crops.

Jimenez has also identified another concern in the small-scale farming community - the difficulty of using agrichemicals in crop production. Working with IPM weed ecologist Tim Prather, he developed a prototype "bicycle sprayer," named for the mountain-bike tires on which the hand-pulled rig navigates through row crops or trellis plantings.

"Small-scale farmers often grow a variety of crops, which might have different row sizes, grow to different heights and each have particular needs at different times in the growing season," Jimenez says.

The bicycle sprayer, which can be purchased for about $\$ 3,000$ or home-built with UC's plans, is fully adjustable.

"We wanted to help farmers get away from using backpack and spot sprayers, which can be inefficient, less precise and, because of the workers' proximity to the material being applied, sometimes dangerous," Prather says.

UC's wealth of research-based production information is worthless to the state's small-scale producers unless they receive it, understand it and put it to use. The farm advisors frequently visit farms to provide one-on-one consultations about specific pests, diseases and other production issues.

Some of the conventional extension systems - such as field days, workshops, handbooks, pamphlets and newsletters - are not as effective with farmers with limited English skills or those unaccustomed to traditional educational programs. To better reach those farmers, the Small Farm Program advisors are turning to radio.

Tulare County farm advisor Manuel Jimenez drives to Fresno every other week to answer listener questions on Stella Romo's live Spanishlanguage call-in talk show Comentarios $y$ Entrevistas (Commentaries and Interviews) on KGST.

He remembers a call he took from a grower who found it impossible to grow squash in the fall because viral diseases destroyed the crop. "I told him about virus-resistant squash varieties and reopened the fall squash market to him," Jimenez says. "Experienced farmers might take that for granted, but entry-level growers may not yet know. By listening to the radio, they can capture the information."

Creativity and innovation combined with cutting edge research and effective extension programs have been the hallmark of the Small Farm Program's efforts to sustain small, family farms in California during the past two decades. The successful formula will be the foundation of the program's continuing effort to bolster an agricultural sector that is as much a part of the nation's future as it has been a part of its past.

"The small family farm has always been an important institution in the history of our culture," Jolly says. "And a vibrant, dynamic and healthy small farm sector is essential to sustainable agriculture in the 21st century."

- Jeannette Warnert and Susan McCue 